\title{
Peningkatan Hasil Belajar Fisika Dalam Pembelajaran Daring Menggunakan Platform E-learning Madrasah dan Zoom Cloud Meeting Di MAN 1 Samarinda Tahun Ajaran 2020/2021
}

\author{
Nadya Berliana Hidayati ${ }^{1 *}$, Muliati Syam, dan Laili Komariyah ${ }^{3}$ \\ $1^{*}$ Fakultas Keguruan dan IImu Pendidikan, Universitas Mulawarman \\ Jalan Kuaro, Gunung Kelua, Samarinda, 75119 \\ *nadyaberliana99@mail.com
}

\begin{abstract}
Abstrak
Pandemi covid-19 yang melanda dunia mempengaruhi bidang pendidikan. Perubahan metode pembelajaran dari tatap muka berubah menjadi pembelajaran jarak jauh untuk menghindari penyebaran covid-19. Penelitian ini dilakukan pada saat masih mewabahnya covid-19, sehingga melalui pembelajaran daring peserta didik dapat mengikuti kegiatan pembelajaran seperti biasa walaupun harus berada dalam tempat yang berbeda. Penelitian ini bertujuan untuk mengetahui peningkatan hasil belajar peserta didik MAN 1 Samarinda setelah mengikuti pembelajaran menggunakan E-learning. Teknik pengambilan sampelnya yaitu purposive sampling dengan sampel kelas XI IPA 1 sejumlah 36 peserta didik. Jenis penelitian ini adalah penelitian kuantitatif dengan desain one group pretest-posttest design. Dari analisis yang telah dilakukan menunjukkan bahwa kelas XI IPA 1 memperoleh $\mathrm{N}$-gain 0,72 yang dimana masuk dalam kategori tinggi dengan rata-rata hasil belajar sebesar 78,92. Pengujian hipotesis menggunakan uji t-berpasangan memperoleh nilai signifikan sebesar 0,000, sehingga dapat disimpulkan bahwa terdapat peningkatan hasil belajar peserta didik dalam pembelajaran daring menggunakan platform e-learning madrasah dan zoom cloud meeting. Selain itu, platform ini juga sesuai untuk memfasilitasi kegiatan pembelajaran daring selama masa pandemi.
\end{abstract}

Kata kunci: e-learning madrasah, zoom cloud meeting, hasil belajar

\section{Abstract}

The COVID-19 pandemic that has hit the world has affected the education sector. Changes in learning methods from face-to-face to distance learning has to conduct to avoid the spread of COVID-19. This research was conducted while the Covid-19 outbreak, students could take part in learning activities as usual, even though they had to be in a different place. This study aims to determine the increase in student learning outcomes of MAN 1 Samarinda after the treatment. The sampling technique is purposive sampling with a sample of 36 students in class XI IPA 1. This type of research is quantitative research with a one group pretest-posttest design. From the analysis, it shows that our participants obtained an $\mathrm{N}$-gain of 0.72 which is included in the high category with an average learning outcome of 78.92. Hypothesis testing using paired t-test obtained a significant value of 0.000 , so it can be concluded that there is an increase in student learning outcomes in online learning using the madrasa elearning platform and zoom cloud meeting. In addition, this platform is also suitable for facilitating online learning activities during the pandemic.

Keywords: madrasah e-learning, zoom cloud meeting, learning outcomes

\section{Article History: Received: 7 June 2021 Accepted: 29 October 2021 \\ Revised : 26 November 2021 \\ Published: 30 November 2021}

How to cite: Hidayati, N.B., Syam, M., dan Komariyah, L. (2021). Peningkatan Hasil Belajar Fisika Dalam Pembelajaran Daring Menggunakan Platform E-learning Madrasah dan Zoom Cloud Meeting Di MAN 1 Samarinda Tahun Ajaran 2020/2021, Jurnal Literasi Pendidikan Fisika, 2 (2). pp. 133-142 Retrieved from http://jurnal.fkip.unmul.ac.id/index.php/JLPF

Copyright @ November 2021, Jurnal Literasi Pendidikan Fisika 
Peningkatan Hasil Belajar...

\section{PENDAHULUAN}

Belajar adalah kegiatan untuk mengembangkan pengetahuan, keterampilan, dan sikap dalam ranah baru yang terjadi ketika seseorang berinteraksi dengan lingkungan dan informasi yang didapatnya. Selain adanya interaksi antara peserta didik dengan lingkungannya, kegiatan belajar juga dapat dianggap berlangsung karena adanya interaksi komunikasi yang dilakukan antara pendidik dan peserta didik. Sehingga dari aspek-aspek yang diperoleh peserta didik tersebut dapat diukur pencapaiannya berdasarkan materi pelajaran yang ada di sekolah dan dapat disebut juga sebagai hasil belajar. Tercapai atau tidaknya tujuan pendidikan salah satunya dapat dilihat melalui hasil belajar peserta didik yang mencakup kognitif, afektif, dan psikomotorik. Oleh karena itu, pendidik harus mampu mengorganisir dan mengatur suasana belajar dan menggunakan instrumen yang dapat merangsang dan menantang. Namun, hal ini cukup berat direalisasikan karena adanya pandemi covid19 (Kusuma J., 2020).

Adanya virus corona yang membahayakan ini telah membawa dampak yang tidak kecil bagi dunia. Penyebaran virus tersebut menyebabkan angka kematian yang paling banyak untuk saat ini (Rahcmat, 2020). Negara yang telah terinfeksi virus corona melakukan social distancing (pembatasan jarak sosial) untuk meminimalisir terjadinya interaksi dalam jumlah banyak, di mana individu mungkin telah terinfeksi virus corona tetapi tidak bergejala sehingga belum teridentifikasi dan belum terisolasi (Darmalaksana, 2020). Hal ini secara signifikan mempengaruhi semua bidang dalam kehidupan. Sehingga banyak tempat-tempat umum, lembaga pendidikan, pusat perbelanjaan dan lain sebagainya yang ditutup (Dwi, 2020).

Strategi-strategi yang dilakukan untuk mengurangi penyebaran virus corona berdampak pada berbagai bidang di seluruh dunia termasuk bidang pendidikan. Pendidikan formal yang seharusnya dilakukan secara tatap muka langsung di sekolah, kini harus terkendala karena adanya pandemi ini. Solusi yang bisa dilakukan untuk mengatasi kendala ini adalah dengan melakukan pembelajaran melalui daring (dalam jaringan) atau online (Kusuma Y., 2020).

Pembelajaran dalam jaringan, online atau pembelajaran jarak jauh berarti memenuhi pedoman pembelajaran dengan menggunakan teknologi yang memanfaatkan PC atau perangkat untuk menghubungkan peserta didik dan guru satu sama lain. Dengan menggunakan teknologi, pembelajaran dan latihan bagaimanapun dapat diselesaikan dengan baik meskipun tidak menumpuk di tempat yang sama (Pakpahan, 2020). Pembelajaran yang tidak terikat waktu dan tatap muka virtual merupakan kelebihan dari pembelajaran berbasis web ini (Syarifuddin, 2020).

Kegiatan belajar mengajar yang telah berubah luar biasa secara signifikan ini mempengaruhi dunia pendidikan. Dalam kondisi yang berubah seperti ini pendidik atau peserta didik dan yang terkait lainnya harus mengikuti kemajuan teknologi informasi dalam ranah pendidikan. Salah satu penyebab terjadinya perubahan yang sangat besar ini adalah karena pembelajaran melalui internet dilakukan secara tidak terduga, hal ini secara signifikan mempengaruhi kesiapan sekolah, guru dan peserta didik dalam melakukan sistem pembelajaran jarak jauh. Selain itu, efek pandemi corona yang melanda menyebabkan pembelajaran tidak berjalan secara ideal dengan alasan mereka harus tetap di rumah menerapkan physical distancing (Arizona et al., 2020). Dengan belajar di rumah tentu akan menimbulkan masalah baru bagi guru dan peserta didik. Sejalan dengan itu, upaya dan opsi yang berbeda harus dilakukan sehingga ada peningkatan besar meskipun pembelajaran dilakukan secara online.

Pembelajaran daring menjadi ancaman baru bagi para tenaga pendidik yang menuntut mereka harus memilih strategi pembelajaran yang tepat dengan menguasai media pembelajaran daring untuk menunjang kegiatan pembelajaran yang diharapkan mampu berkreasi supaya tujuan pembelajaran yang sebenarnya dapat dicapai secara maksimal (Mantra, 2020). Satuan pendidikan perlu memilih dan memilah untuk menggunakan platform pembelajaran online yang bisa digunakan oleh peserta didik dan guru, bukan hanya ekonomis dan terjangkau dari segi harga tetapi juga bersifat user-friendly sehingga memudahkan guru, peserta didik dan admin dalam penggunaannya serta yang tidak kalah pentingnya yaitu memiliki fitur lengkap sehingga dapat mendukung pelaksanaan pembelajaran daring secara maksimal. Oleh karena itu, kementrian agama RI merancang e-learning madrasah sebagai platform pembelajaran online. (Salman, 2020).

Hasil penelitian yang relevan dilakukan oleh Hikmah (2020) menunjukkan bahwa e-learning madrasah bisa menjadi sarana dan pilihan utama untuk terlaksananya kegiatan belajar mengajar peserta didik MIN 1 Rembang pada masa pandemi covid-19 sekarang ini. Selain itu, penelitian yang dilakukan oleh Nisa (2020) memberikan hasil bahwa analisis angket menunjukkan bahwa respon peserta didik termasuk dalam kategori baik dan analisis hasil belajar menunjukkan bahwa kelas X TKRO 2 memperoleh $N$-Gain sebesar 0,59 yang terkategori sedang dengan rata-rata hasil belajar sebesar 70,20. Pengujian hipotesis dengan menggunakan uji-t berpasangan diperoleh nilai signifikan sebesar 0,000. Sehingga dapat disimpulkan bahwa terdapat pengaruh model e-learning berbantuan google classroom dan zoom cloud meeting terhadap hasil belajar peserta didik. Platform sinkronous menunjukkan hasil yang lebih positif (Meliana, et al, 2021). 
Peningkatan Hasil Belajar...

Berdasarkan observasi dan wawancara yang dilakukan oleh peneliti, serta berdasarkan pengalaman selama melaksanakan PLP-KKN ditemui bahwa sekolah menjalani pembelajaran daring akibat pandemi ini. Sekolah mau tidak mau harus menyesuaikan keadaan dengan menggunakan media online agar bisa terhubung dengan peserta didiknya walaupun berada di tempat yang berbeda. Khususnya MAN 1 Samarinda menggunakan $e-$ learning madrasah yang difasilitasi oleh Kementrian Agama Pusat untuk melakukan proses pembelajaran. Elearning madrasah telah dilengkapi berbagai fitur yang mendukung proses pembelajaran, hanya saja dalam elearning tersebut fitur video conference yang tersedia tidak bisa digunakan secara maksimal sehingga interaksi yang berjalan melalui e-learning kurang efektif. Maka untuk meningkatkan hasil belajar peserta didik dalam kondisi yang luar biasa ini, alternatif tindakan yang dapat dilakukan adalah menggunakan platform pembelajaran yang dapat memudahkan peserta didik dalam proses pembelajaran agar mendapatkan hasil belajar yang baik, yaitu dengan sistem synchronous learning yang dapat menghubungkan pendidik dan peserta didik sehingga bisa saling berinteraksi tatap muka virtual walaupun berada di tempat yang berbeda.

Menurut Arisandhy (2013), dalam lingkungan e-learning saat ini jenis pembelajaran yang terjadi umumnya dibagi ke dalam salah satu dari dua kategori : synchronous dan asynchronous. Kedua strategi memiliki pro dan kontra mereka sendiri, dan teknik yang tepat untuk peserta didik sangat tergantung pada metode mereka menyerap informasi yang disediakan.

Synchronous learning ini juga merupakan metode penyampaian bahan ajar e-learning. Masing-masing kategori tersebut pada dasarnya mengacu pada bagaimana perasaan seorang peserta didik pada saat melakukan proses pembelajaran dengan sistem e-learning. Synchronous berarti "waktu yang sama". Pembelajaran ini adalah tipe dimana pembelajaran eletronik dilakukan atau dilaksanakan pada saat yang sama dimana pendidik sedang mengajar, dan peserta didik sedang belajar. Hal tersebut memungkinkan interaksi langsung antara pendidik dan peserta didik, baik itu melalui internet, maupun melalui intranet. Penggunaan $e-$ learning tipe ini biasanya digunakan pada konferensi yang pesertanya berasal dari beberapa daerah. Aktivitas tersebut dikenal juga dengan istilah 'web conference' atau 'webinar'. Selain digunakan pada aktivitas tersebut, synchronous learning juga sering digunakan pada kelas online. Synchronous learning mengharuskan pendidik dan peserta didik untuk mengakses sistem e-learning secara bersamaan. Singkatnya, e-learning tipe ini hampir sama dengan pembelajaran langsung di ruang kelas (konvensional) hanya saja pada synchronous learning hal ini tidak ditandai dengan kehadiran secara fisik. Namun kelasnya bersifat virtual dan menggunakan media komputer yang terkoneksi dengan internet.

Asynchronous e-learning adalah metode pengajaran yang berpusat pada peserta didik yang menggunakan sumber belajar online untuk memudahkan berbagi di luar batasan waktu dan tempat di antara jaringan informasi. Asynchronous e-learning didasarkan pada teori konstruktivis, pendekatan yang berpusat pada peserta didik yang menekankan pentingnya interaksi peer-to-peer. Pendekatan ini menggabungkan belajar mandiri dengan interaksi asynchronous untuk meningkatkan pembelajaran dan dapat digunakan untuk memfasilitasi pembelajaran dalam pendidikan tradisional, pendidikan jarak jauh, dan pendidikan berkelanjutan. Jaringan ini adalah gabungan dari peserta didik dengan jaringan elektronik tempat di mana mereka berkomunikasi disebut sebagai asynchronous learning network. Asynchronous learning di sisi lain dapat dilakukan bahkan ketika peserta didik atau pengajar sedang offline. Kursus dan komunikasi yang disampaikan melalui email dan pesan yang diposting di forum komunitas adalah contoh sempurna dari asynchronous learning. Dalam hal ini, peserta didik biasanya akan menyelesaikan pelajaran mereka sendiri dan hanya menggunakan internet sebagai alat pendukung dibandingkan harus online pada waktu tertentu hanya sematamata untuk kelas interaktif.

Berdasarkan pemaparan latar belakang tersebut, peneliti berinisiatif melakukan penelitian untuk mencari tahu bagaimana peningkatan hasil belajar fisika dengan menggunakan dua platform yang berbeda. Platform yang digunakan dalam penelitian ini adalah platform e-learning madrasah (asynchronous learning) dan zoom cloud meeting (synchronous learning). Sehingga peneliti tertarik untuk melakukan penelitian dengan judul "Peningkatan Hasil Belajar Fisika Dalam Pembelajaran Daring Menggunakan Platform E-learning Madrasah dan Zoom Cloud Meeting di MAN 1 Samarinda Tahun Ajaran 2020/2021" pada materi gelombang mekanik. Dengan judul ini peneliti akan membuktikan bahwa apakah terdapat peningkatan hasil belajar fisika menggunakan dua platform pembelajaran tersebut. Harapannya adalah dengan menggunakan platform pembelajaran ini dapat meningkatkan pemahaman peserta didik sehingga hasil belajar fisika peserta didik bisa meningkat dengan baik.

\section{METODE}

Jenis penelitian pada penelitian ini adalah penelitian kuantitatif, dimana data penelitian yang disajikan berupa angka dan dianalisis menggunakan statistik. Metode penelitian yang digunakan adalah jenis pre- 
Peningkatan Hasil Belajar...

eksperimental designs yang bersifat One Group Pretest-Posttest. Dengan menggunakan design ini subjek penelitian digunakan hanya satu kelompok. Kelompok yang akan diberi perlakuan ini diberi tes awal (pretest), kemudian peneliti melakukan perlakuan berupa kegiatan belajar mengajar menggunakan platform e-learning madrasah dan zoom cloud meeting. Setelah itu, kelompok tersebut diberi tes akhir (posttest). Besarnya peningkatan dapat diketahui dengan cara membandingkan antara hasil pre-test dan post-test. Penelitian ini dilakukan di MAN 1 Samarinda pada bulan Februari-Maret 2020 tahun ajaran 2020/2021 semester genap, dengan sampel penelitian kelas XI IPA 1 MAN 1 Samarinda sebanyak 36 peserta didik yang diambil menggunakan teknik purposive sampling, yaitu teknik pengambilan sampel dengan pertimbangan tertentu.

Teknik pengumpulan data yang digunakan dalam peenlitian ini adalah teknik tes untuk mengukur hasil belajar peserta didik. Tes yang digunakan dalam penelitian ini adalah tes tertulis kognitif pretest-posttest berbentuk essay sebanyak 10 soal dalam ranah kognitif $\mathrm{C} 2$ hingga $\mathrm{C} 4$. Soal pretest diberikan diawal pertemuan dalam pembelajaran materi gelombang mekanik untuk mengetahui pengetahuan awal peserta didik dan soal post-test diberikan diakhir pertemuan dalam pembelajaran materi gelombang mekanik untuk mengetahui hasil belajar peserta didik setelah diberi perlakuan berupa penggunaan media platform e-learning madrasah dan zoom cloud meeting.

Setelah mendapatkan data, peneliti menganalisis hasil belajar peserta didik menggunakan rumus rata-rata skor yang diperoleh peserta didik pada saat pretest dan posttest. Kemudian dilakukan perhitungan $N$-Gain untuk mengetahui peningkatan pada pretest dan posttest. Lalu peneliti melakukan pengujian hipotesis untuk memutuskan apakah ada atau tidaknya peningkatan hasil belajar fisika yang signifikan dalam pembelajaran daring menggunakan platform e-learning madrasah dan zoom cloud meeting. Analisis peningkatan menggunakan uji t-berpasangan dengan uji prasyarat berupa uji normalitas yang diselesaikan dengan bantuan software IBM SPSS Statistics 20.0 for Windows.

\section{HASIL DAN PEMBAHASAN}

Sebelum peneliti memberikan perlakuan, peneliti melakukan pretest yang direncanakan untuk mengukur kemampuan awal peserta didik. Pretest dilakukan selama 2 jam pelajaran saat pertemuan pertama. Tes yang diberikan berupa soal uraian (essay) berjumlah 10 soal dengan skor alternatif untuk setiap soal yang disesuaikan dengan tingkat kesulitan soal. Jumlah data prestest yang dianalisis dalam penelitian ini adalah 36 sesuai dengan jumlah peserta didik di kelas sampel yaitu kelas XI IPA 1. Hasil pretest peserta didik dapat dilihat pada gambar 1.

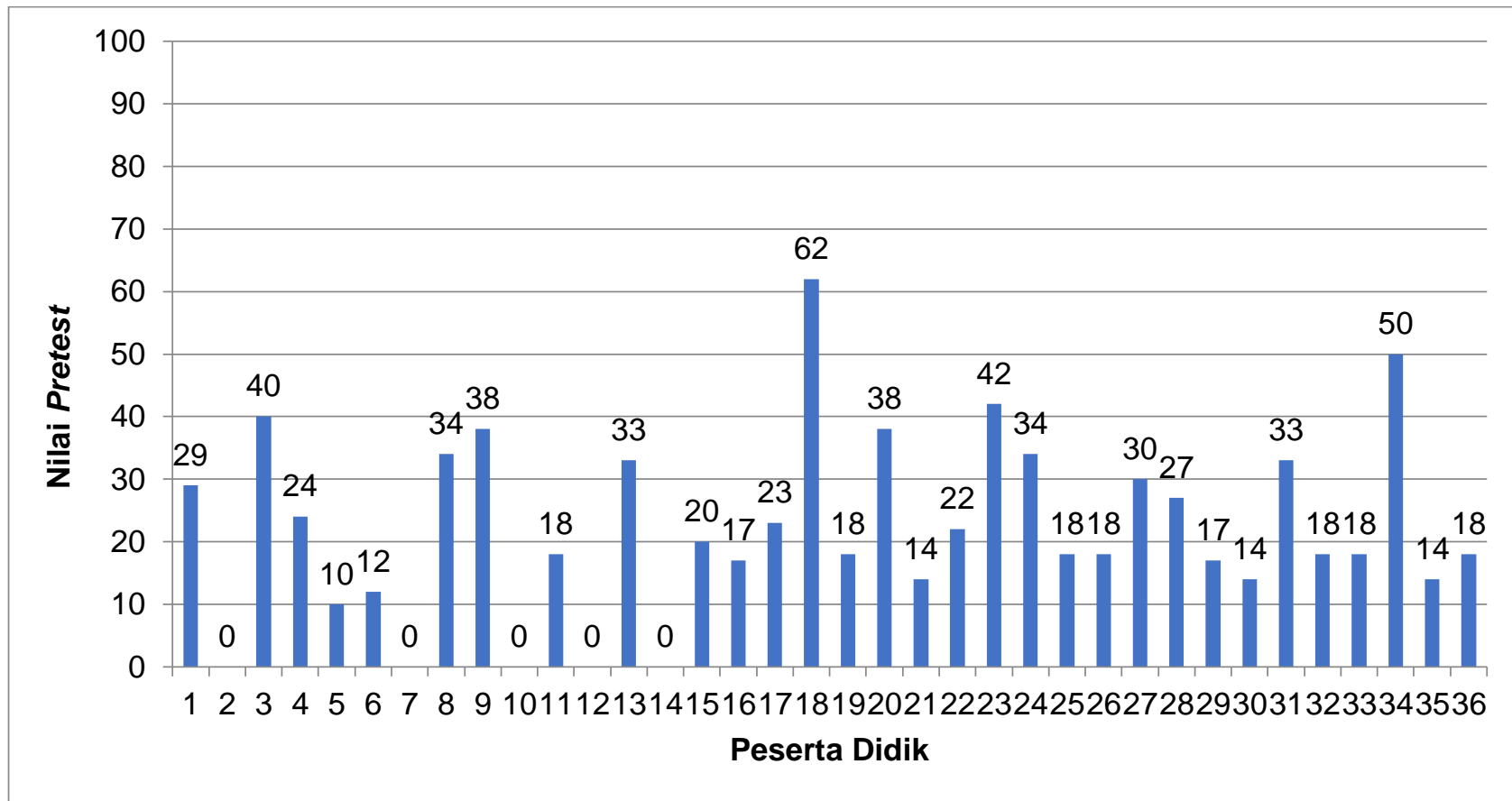

Gambar 1. Grafik Hasil Pretest Peserta Didik

Berdasarkan Gambar 1 hasil pretest pada kelas sampel menunjukkan bahwa peserta didik mendapat nilai

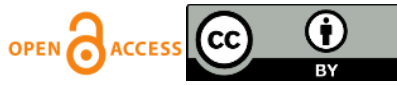


Peningkatan Hasil Belajar...

dari rentang 0 hingga 62 . Terdapat 5 peserta didik yang mendapat nilai paling rendah yaitu 0 , sedangkan nilai yang paling tinggi adalah 62 .

Setelah peneliti memberi perlakuan berupa kegiatan belajar mengajar menggunakan platform e-learning madrasah dan zoom cloud meeting, peneliti melakukan posttest untuk mengukur kemampuan akhir peserta didik atau hasil belajar kognitif peserta didik. Pemberian posttest dilakukan pada saat pertemuan terakhir selama 2 jam pelajaran. Tes yang diberikan sama dengan tes pada saat pretest. Jumlah data pun sama dengan data saat pretest yaitu 36 sesuai dengan jumlah peserta didik di kelas sampel yaitu kelas XI IPA 1. Hasil posttest peserta didik dapat dilihat pada Gambar 2.

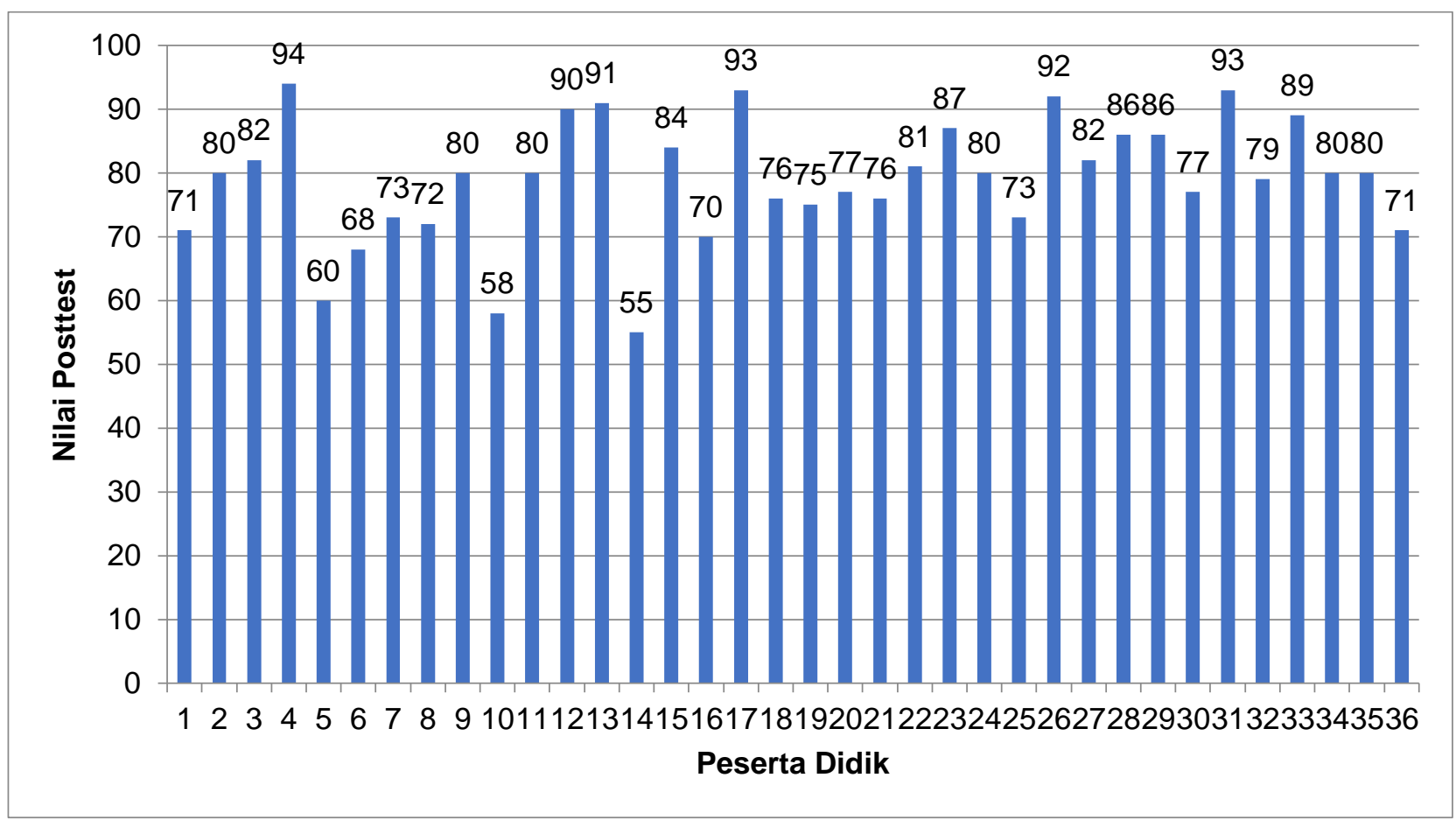

Gambar 2. Grafik Hasil Posttest Peserta Didik

Berdasarkan Gambar 2 hasil posttest pada kelas sampel menunjukkan bahwa peserta didik mendapat nilai dari rentang 55 hingga 94. Setelah diberi perlakuan berupa penggunaan platform e-learning madrasah dan zoom cloud meeting dalam pembelajaran daring, hasil posttest pada kelas sampel lebih tinggi dibandingkan dengan hasil pretest. Untuk mengetahui rata-rata skor pretest dan posttest peserta didik dapat dilihat pada Tabel 1 dibawah ini.

Tabel 1. Hasil Rata-Rata Pretest dan Posttest Peserta Didik

\begin{tabular}{cccccc}
\hline & $\mathrm{N}$ & Minimum & Maximum & \multicolumn{2}{c}{ Mean } \\
\cline { 2 - 6 } & Statistic & Statistic & Statistic & Statistic & Std. Error \\
\hline Pretest & 36 & 0 & 62 & 22.31 & 2.409 \\
\hline Posttest & 36 & 55 & 94 & 78.92 & 1.603 \\
\hline Valid N (listwise) & 36 & & & \\
\hline
\end{tabular}

Berdasarkan data yang diperoleh pada tabel 1 diketahui jika ada peningkatan nilai rata-rata hasil belajar pretest dan posttest pada kelas sampel dari 22,31 menjadi 78,92 dengan sampel sebanyak 36 peserta didik.

Berdasarkan data yang telah diperoleh, kegiatan pembelajaran dengan menggunakan platform e-learning madrasah dan zoom cloud meeting dapat meningkatkan hasil belajar kognitif peserta didik. Walaupun termasuk dalam kategori tinggi, masih terdapat peserta didik yang mendapatkan nilai dibawah KKM. Hal ini disebabkan oleh kurang fokusnya peserta didik dalam kegiatan pembelajaran dan adanya kegiatan lain dirumah peserta didik sehingga peserta didik tidak bisa mengikuti kegiatan pembelajaran dengan baik. Dalam room zoom meeting banyak peserta didik yang mematikan kameranya sehingga pendidik tidak mengetahui kondisi belajar

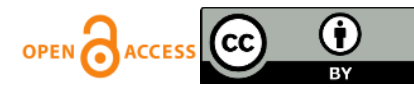


Peningkatan Hasil Belajar...

peserta didik di rumahnya masing-masing. Selain itu, terdapat peserta didik yang tidak tepat waktu memasuki ruang zoom meeting sehingga peserta didik yang lain harus menunggu terlebih dahulu. Hal ini menyebabkan jam pembelajaran mundur tidak sesuai dengan waktu yang telah ditentukan sebelumnya. Bahkan terdapat pula peserta didik yang tidak memasuki ruang zoom meeting. Kendala lainnya yang muncul selama pembelajaran adalah adanya peserta didik yang mengirimkan tugas yang peneliti berikan melalui whattsapp dikarenakan terganggunya sistem e-learning. Selain itu, disebabkan pula oleh faktor jaringan internet yang tidak baik di tempat peserta didik berada.

Tabel 1 menunjukkan perbedaan nilai rata-rata hasil belajar pretest dan posttest peserta didik dengan perbandingan nilai rata-rata posttest lebih tinggi dibandingan dengan nilai rata-rata pretest peserta didik dalam materi gelombang mekanik. Hal ini menunjukkan bahwa platform e-learning madrasah dan zoom cloud meeting dapat meningkatkan hasil belajar peserta didik. Dalam e-learning madrasah peserta didik yang telah tergabung dalam kelasnya masing-masing dapat mengikuti kegiatan pembelajaran yang telah ditentukan dengan baik khususnya dapat melakukan absensi, melihat bahan ajar yang telah dibagikan guru sebagai salah satu sumber belajar peserta didik, dapat mengumpulkan tugas, dan dapat mengerjakan ujian di dalam e-learning madrasah, serta pendidik dapat merekap hasil pekerjaan peserta didik melalui e-learning madrasah. Kegiatan pembelajaran ini dibuat semakin baik dengan menggunakan platform tambahan yaitu zoom cloud meeting, selama proses pembelajaran peserta didik dapat bertemu dengan guru dan peserta didik lainnya walaupun berada dalam tempat yang berbeda. Di dalam room zoom meeting pendidik dapat menjelaskan materi secara lisan dan melakukan diskusi dan tanya jawab bersama peserta didik. Selain dapat meningkatkan hasil belajar peserta didik, kegiatan pembelajaran dengan menggunakan platform e-learning madrasah dan zoom cloud meeting juga dapat menjadi jawaban untuk pembelajaran jarak jauh yang saat ini dilakukan karena virus covid19.

Kenaikan skor posttest yang tidak teratur diantaranya disebabkan oleh kurang dikontrolnya proses pembelajaran karena pembelajaran online sehingga berada di tempat yang berbeda. Selain itu, tingkat fokus peserta didik dalam mengerjakan soal juga berpengaruh. Hal tersebut menyebabkan beberapa peserta didik mendapat skor pretest paling tinggi dari seluruh sampel namun kenaikan skor posttestnya hanya sedikit sehingga tidak mendapat skor paling tinggi. Ada pula peserta didik yang mendapat skor rendah saat pretest mendapat skor tinggi saat posttest. Hal ini dapat disebabkan oleh kondisi belajar peserta didik yang relax di rumah masing-masing sehingga meningkatkan motivasi belajar dan instrumen soal pretest dan posttest yang dibuat oleh peneliti dibuat mirip dengan soal evaluasi pada saat pertemuan pembahasan materi sehingga menambah kemampuan siswa dalam menyelesaikan soal-soal tersebut.

Untuk mengatasi permasalahan seperti ini dengan sistem pembelajaran daring yang sedang dijalankan terutama pada saat pandemi, guru dapat melakukan upaya yang berbeda, termasuk memberi bimbingan peserta didik untuk belajar mengambil informasi dari sumber yang valid.

$\mathrm{N}$-Gain memberikan gambaran umum peningkatan hasil belajar peserta didik antara pretest dan posttest. Hasil analisis perolehan $N$-Gain terhadap hasil belajar peserta didik disajikan dalam tabel 2.

Tabel 2. Perolehan nilai $N$-Gain

\begin{tabular}{cccc}
\hline Rata-rata pretest & Rata-rata posttest & $N$-Gain & Kriteria \\
\hline 22,31 & 78,92 & 0,72 & Tinggi \\
\hline
\end{tabular}

Berdasarakan tabel 2 perolehan $\mathrm{N}$-Gain pada kelas sampel yang diperoleh adalah 0,72 sehingga termasuk dalam kategori tinggi. Hasil $N$-Gain peserta didik cenderung pada kategori tinggi dan sedang. Untuk memperjelas data klasifikasi $N$-Gain, maka dapat disajikan dalam bentuk grafik seperti pada gambar 3 . 
Peningkatan Hasil Belajar...

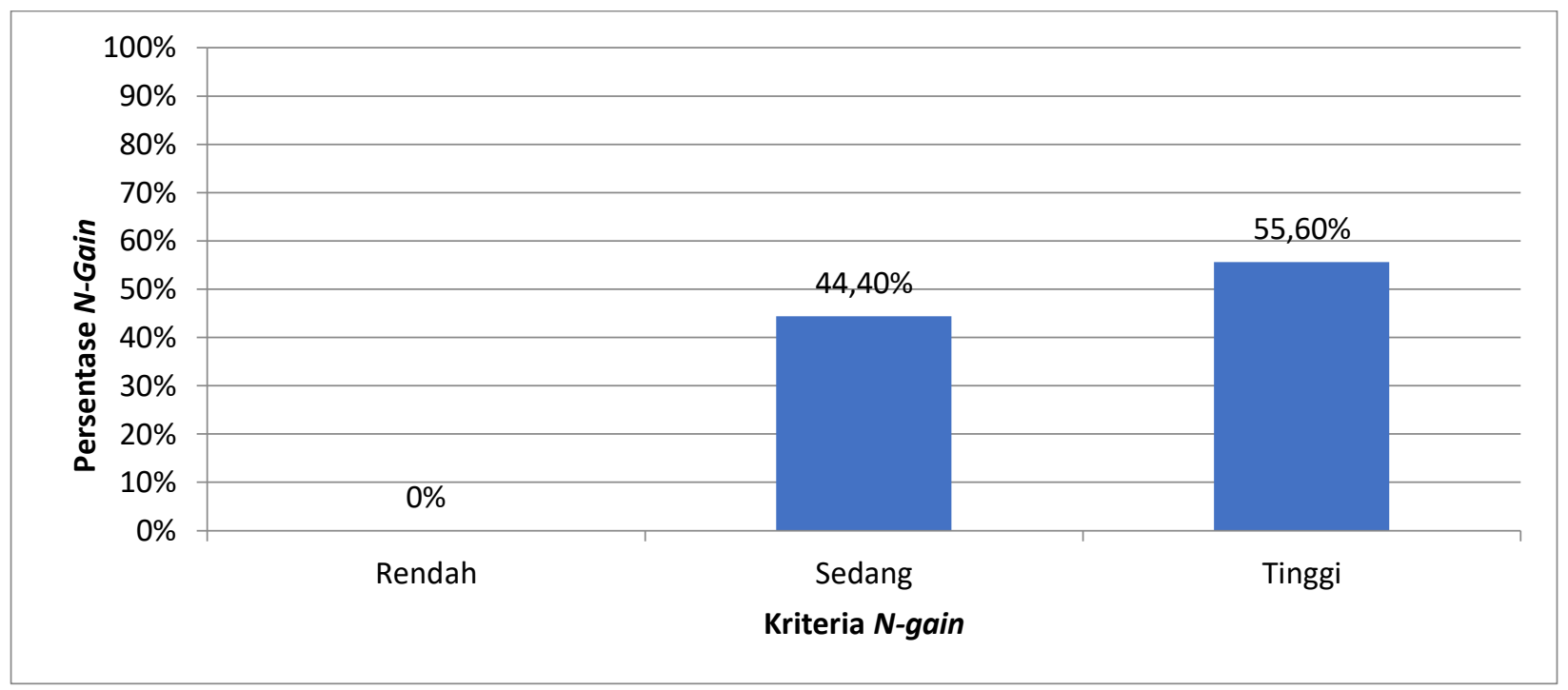

Gambar 3. Grafik Hasil N-Gain Peserta didik

Peningkatan hasil belajar peserta didik sebelum dan sesudah diberi perlakuan berada pada kategori tinggi. Pada saat pembelajaran online, peserta didik diberi kebebasan untuk menemukan pengetahuannya sendiri dari berbagai sumber baik offline maupun online, terkecuali pada saat tes. Pengetahuan yang ditemukan sendiri ini menjadi salah satu dari penyebab meningkatnya hasil belajar peserta didik menjadi lebih baik karena peserta didik akan lebih mengingat pengetahuan yang mereka dapatkan sendiri.

Adanya hasil belajar yang kurang ideal bagi peserta didik disebabkan oleh beberapa alasan, antara lain akses dan kontrol internet dalam interaksi pembelajaran. Pembelajaran berbasis web (online) ini membutuhkan akses web yang bagus, jadi peserta didik dan guru harus memiliki kuota dan jaringan internet yang baik. Selain itu, kegiatan pembelajaran tidak sepenuhnya terkontrol, karena hanya menekankan kejujuran dan kemandirian peserta didik dalam belajar.

Pengujian hipotesis dalam penelitian ini menggunakan uji-t berpasangan. Sebelum dilakukan uji t, terlebih dahulu harus dilakukan uji prasyarat terlebih dahulu yaitu dengan uji normalitas. Uji t berpasangan dan uji normalitas diolah dengan bantuan pemrograman IBM SPSS Statistics 20.0 for Windows. Uji normalitas yang digunakan adalah uji Shapiro Wilk. Data yang diperoleh dapat diklasifikasikan normal jika taraf signifikansinya lebih dari 0,05 . Hasil uji normalitas hasil belajar pretest dan posttest dapat dilihat pada tabel 3.

Pengujian hipotesis pada penelitian ini menggunakan uji t-berpasangan. Sebelum dilakukan uji $t$ berpasangan terlebih dahulu harus dilakukan uji prasyarat yaitu uji normalitas. Uji t berpasangan dan uji normalitas dianalisis dengan bantuan software IBM SPSS Statistics 20.0 for Windows. Uji normalitas yang digunakan dalam penelitian ini adalah uji Shapiro Wilk. Data dapat dikategorikan terdistribusi dengan normal apabila nilai taraf signifikansinya lebih besar dari 0,05 . Hasil uji normalitas data hasil belajar pretest dan posttest pada lampiran dapat disajikan dalam tabel 3.

Tabel 3. Hasil Uji Normalitas Data Hasil Belajar

\begin{tabular}{ccccc}
\hline \multirow{2}{*}{ Hasil Belajar } & \multicolumn{3}{c}{ Shapiro-Wilk } \\
\cline { 2 - 4 } & Statistic & $\mathrm{df}$ & Sig. \\
\hline Pretest & .951 & 36 & .109 \\
\hline Posttest & .956 & 36 & .159 \\
\hline
\end{tabular}

Berdasarkan hasil pengujian pada tabel 3, dapat dilihat bahwa hasil uji normalitas data hasil belajar pretest sebesar 0,109 sedangkan hasil uji normalitas data hasil belajar posttest sebesar 0,159 sehingga dapat disimpulkan data hasil belajar pretest dan posttest yang diperoleh terdistribusi dengan normal.

Berdasarkan hasil uji normalitas yang merupakan uji prasyarat dilakukannya uji t-berpasangan, diketahui bahwa data hasil belajar pretest dan posttest tersebar secara normal. Oleh karena itu, uji hipotesis yang dilakukan adalah menggunakan uji t-berpasangan. Uji t-berpasangan digunakan untuk mengetahui apakah terdapat peningkatan yang signifikan antara hasil belajar pretest dan posttest. Hasil uji t-berpasangan yang dilakukan pada hasil belajar pretest dan posttest disajikan dalam tabel 4 berikut. 
Peningkatan Hasil Belajar...

Tabel 4. Hasil Uji T-Berpasangan

Paired Samples Test

\begin{tabular}{ccccccc}
\hline & \multicolumn{3}{c}{ Paired Differences } & & & \\
\cline { 2 - 7 } Pretest-Posttest & Mean & $\begin{array}{c}\text { Std. } \\
\text { Deviation }\end{array}$ & $\begin{array}{l}\text { Std. Error } \\
\text { Mean }\end{array}$ & t & df & $\begin{array}{c}\text { Sig. } \\
\text { tailed) }\end{array}$ \\
\cline { 2 - 7 } & & 14.545 & 2.424 & -23.353 & 35 & .000 \\
\hline
\end{tabular}

Tabel 4 menunjukkan bahwa nilai signifikansi yang diperoleh lebih kecil dari 0,05 yaitu 0,000. Berdasarkan hasil tersebut dapat disimpulkan bahwa terdapat peningkatan signifikan pada hasil belajar pretest dan posttest peserta didik terhadap penggunaan platform e-learning madrasah dan zoom cloud meeting pada materi gelombang mekanik.

Penelitian yang telah dilakukan ini menunjukkan bahwa penggunaan platform e-learning madrasah dan zoom cloud meeting dapat meningkatkan hasil belajar peserta didik. Dengan adanya perbedaaan yang signifikan pada hasil pretest dan posttest peserta didik, maka dapat dikatakan bahwa terdapat peningkatan hasil belajar peserta didik dalam pembelajaran daring menggunakan platform e-learning madrasah dan zoom cloud meeting. Pada pembelajaran online (daring), peserta didik diberi kebebasan untuk menemukan pengetahuannya sendiri diluar bahan ajar yang telah diberikan peneliti melalui e-learning madrasah, adanya platform zoom meeting juga memudahkan peserta didik untuk memahami materi dengan penjelasan peneliti dan tanya jawab bersama dalam room meeting. Selain itu, peserta didik juga dapat belajar secara mandiri menggunakan bahan ajar yang telah diberikan pendidik di e-learning madrasah sehingga bisa diakses kapan saja dan dimana saja dengan akses internet yang baik. Hal ini mengakibatkan hasil belajar peserta didik menjadi lebih baik.

Hal ini sejalan dengan penelitian yang dilakukan oleh Al-Mu'min dan llyas (2020) yang menunjukkan adanya pengaruh hasil belajar pada pembelajaran online berbasis zoom cloud meeting di Program Studi Pendidikan Fisika Universitas Flores, serta sejalan dengan penelitian yang dilakukan oleh Kusuma dan Hamidah (2020) yang menunjukkan adanya peningkatan hasil belajar mahapeserta didik mata kuliah matematika ekonomi di Universitas Bina Bangsa Serang dengan menggunakan zoom cloud meeting daripada menggunakan whattsapp.

Faktor-faktor yang menyebabkan hasil belajar peserta didik meningkat diantaranya adalah :

a. Aspek Konten

Penggunaan e-learning madrasah yang ditambah dengan zoom cloud meeting menjadi pelengkap dalam kegiatan belajar mengajar dalam jarak jauh atau pembelajaran daring. Dengan e-learning madrasah peserta didik dapat mengakses bahan ajar dari guru dengan tidak terbatas tempat dan waktu sehingga peserta didik dapat belajar mandiri diluar waktu pelajaran fisika. Kemudian dengan tambahan video conference menggunakan zoom meeting peserta didik dapat saling berinteraksi dalam pembelajaran sehingga hal itu dapat meningkatkan hasil belajar peserta didik.

b. Aspek Fitur

Fitur-fitur dalam e-learning madrasah dan zoom cloud meeting sangat mendukung kegiatan belajar mengajar daring. E-learning madrasah tidak hanya menguntungkan bagi peserta didik, tetapi juga bagi guru, operator, maupun kepala madrasah. Desainnya dibuat lengkap untuk memenuhi proses pembelajaran, dimulai dari form pengisian kompetensi inti dan kompetensi dasar hingga pada penilaian peserta didik, baik penilaian harian maupun penilaian akhir semester.

c. Aspek Situasi

Situasi yang masih mengharuskan pembelajaran daring ini juga mempengaruhi perolehan hasil belajar. Dengan belajar di rumah peserta didik dapat dengan mudah belajar sesuai dengan kenyamanan masingmasing di rumah. Hal itu membuat motivasi belajar meningkat sehingga peserta didik akan lebih mudah menyerap materi yang diberikan.

d. Aspek Motivasi

Motivasi merupakan faktor internal dan eksternal peserta didik. Dengan menggunakan platform e-learning madrasah dan zoom cloud meeting mampu meningkatkan motivasi belajar peserta didik secara internal karena dengan tampilan yang menarik dan penggunaan yang mudah membuat peserta didik nyaman dalam proses pembelajaran. Kemudian faktor motivasi eksternal dapat dipengaruhi dengan memberi dorongan dan membentuk kebiasaan baik dalam belajar. Oleh karena itu, dalam setiap pertemuan kegiatan belajar mengajar guru memberikan motivasi kepada peserta didik agar tidak mengurangi semangat belajarnya walaupun dalam kondisi new normal seperti saat ini.

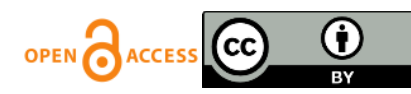


Peningkatan Hasil Belajar...

\section{PENUTUP}

Berdasarkan penelitian yang telah dilakukan di MAN 1 Samarinda kelas XI IPA 1 dan analisis data yang telah dilakukan oleh peneliti mengenai pelaksanaan pembelajaran daring untuk meningkatkan hasil belajar peserta didik menggunakan platform e-learning madrasah dan zoom cloud meeting pada materi gelombang mekanik, maka dapat ditarik kesimpulan bahwa hasil belajar peserta didik di MAN 1 Samarinda pada materi gelombang mekanik sebelum diberi perlakuan pembelajaran daring dengan menggunakan platform e-learning madrasah dan zoom cloud meeting diperoleh rata-rata nilai sebesar 22,31, sedangkan hasil belajar peserta didik di MAN 1 Samarinda pada materi gelombang mekanik setelah diberi perlakuan pembelajaran daring dengan menggunakan platform e-learning madrasah dan zoom cloud meeting diperoleh rata-rata nilai sebesar 78,92 .

Ada ide yang bisa diberikan berdasarkan dari penelitian yang telah dilakukan, khususnya hasil belajar peserta didik dapat ditingkatkan dengan memanfaatkan e-learning madrasah dan zoom cloud meeting yang digabungkan dengan pembelajaran tatap muka di kelas, tidak hanya melalui zoom cloud meeting. Penggunaan e-learning madrasah dan zoom cloud meeting dapat dimanfaatkan sebagai pilihan strategi pembelajaran dalam materi IPA untuk meningkatkan hasil belajar peserta didik dan peningkatan kebebasan belajar serta kapasitas peserta didik untuk memperoleh informasi dan data dari berbagai sumber. Demikian pula pemanfaatan tahapan e-learning madrasah dan zoom cloud meeting dapat dicoba pada topik lain untuk meningkatkan hasil belajar peserta didik.

\section{DAFTAR PUSTAKA}

Arizona, K., Abidin, Z., dan Rumansyah, R. (2020). Pembelajaran Online Berbasis Proyek Salah Satu Solusi Kegiatan Belajar Mengajar Di Tengah Pandemi Covid-19. Jurnal Ilmiah Profesi Pendidikan, 5(1), 6470. https://doi.org/10.29303/iipp.v5i1.111.

Arisandhy, N.S. (2017). Analisis Kemampuan Literasi Media Internet Mahasiswa Dalam Memanfaatkan Fitur Berita Di Line Today. UPI

Darmalaksana, W., Hambali, R., Masrur, A., dan Muhlas, M. (2020). Analisis Pembelajaran Online Masa WFH Pandemic Covid-19 sebagai Tantangan Pemimpin Digital Abad 21. Karya Tulis IImiah (KTI) Masa Work From Home (WFH) Covid-19 UIN Sunan Gunung Djati Bandung. 1-12.

Dwi, B., Amelia, A., Hasanah, U., dan Putra, A. M. (2020). Analisis Keefektifan Pembelajaran Online di Masa Pandemi Covid-19. Jurnal Pendidikan Guru Sekolah Dasar, 2(1), 3.

Hikmah, Shofaul. (2020). Pemanfaatan E-learning Madrasah Dalam Pelaksanaan Pembelajaran Jarak Jauh Masa Pandemi Di MIN 1 Rembang. Edutrained : Jurnal Pendidikan dan Pelatihan. Vol.4 No.2, 73-85.

Kusuma, J. W., dan Hamidah, H. (2020). Perbandingan Hasil Belajar Matematika Dengan Penggunaan Platform Whatsapp Group Dan Webinar Zoom Dalam Pembelajaran Jarak Jauh Pada Masa Pandemik Covid 19. JIPMat, 5(1). https://doi.org/10.26877/iipmat.v5i1.5942.

Kusuma, Y.A. (2020). Efektivitas Penggunaan Aplikasi Quizizz dalam Pembelajaran Daring (Online) Fisika Pada Materi Usaha dan Energi Kelas X MIPA di SMA Masehi Kudus Tahun Pelajaran 2019/2020. Skripsi, Universitas Sanata Darma.

Mantra, I. B. N., Widiastuti, I. A. M. S., dan Pramawati, A. A. I. Y. (2020). Peningkatan Kompetensi Mengajar Secara Online Bagi Para Guru Selama Pandemi Virus Corona. Jurnal Abdi Dharma Masyarakat (JADMA), 1(1), 12-20.

Meliana, Meliana; Junus, Muhammad; Sulaeman, Nurul Fitriyah. Learning Science Through Online System: Whatsapp Vs Google Meet Platform. ScienceEdu: Jurnal Pendidikan IPA, [S.I.], v. 4, n. 1, p. 1-6, apr 2021. ISSN 2685-2071.

Nisa, Komariyah, L. dan Syam, M. (2021). Pengaruh Model Pembelajaran E-learning Berbantuan Google Classroom dan Zoom Cloud Meeting terhadap Hasil Belajar Peserta didik di SMK Negeri 6 Samarinda. Jurnal Kajian Pendidikan IPA. Vol 1, Nomor 1.

Pakpahan, R., \& Fitriani, Y. (2020). Analisa Pemanfaatan Teknologi Informasi dalam Pembelajaran Jarak Jauh di Tengah Pandemi Virus Corona Covid 19. Journal of Information System, Applied, Management, Accounting and Research, 4(2), 30-36.

Rachmat, A. dan Krisnadi, I. (2020). Analisis Efektivitas Pembelajaran Daring (Online) Untuk Siswa SMK Negeri 8 Kota Tanggerang Pada Saat Pandemi Covid-19.

Salman. 2020. "E-learning Madrasah Solusi Pembelajaran Daring Di Masa Pandemi Covid-19 ", https://www.man1kuburaya.sch.id/e-learning-madrasah-solusi-pembelajaran-daring-di-masapandemi-covid-19/, diakses pada 6 April 2021 pukul 10:23 WITA. 
Peningkatan Hasil Belajar...

Syarifudin, A. S. (2020). Impelementasi Pembelajaran Daring Untuk Meningkatkan Mutu Pendidikan Sebagai Dampak Diterapkannya Social Distancing. Jurnal Pendidikan Bahasa dan Sastra Indonesia Metalingua, 5(1), 31-34. 